\title{
Fecal DNA versus Fecal Occult Blood for Colorectal-Cancer Screening in an Average-Risk Population
}

\author{
Thomas F. Imperiale, M.D., David F. Ransohoff, M.D., Steven H. Itzkowitz, M.D., \\ Barry A. Turnbull, Ph.D., and Michael E. Ross, M.D., \\ for the Colorectal Cancer Study Group*
}

ABSTRACT

From the Department of Medicine, Indiana University, and the Regenstrief Institute - both in Indianapolis, (T.F.I.); the Department of Medicine, University of North Carolina at Chapel Hill, Chapel Hill (D.F.R.) the Department of Medicine, Mount Sinai School of Medicine, New York (S.H.I.); CareStat, Newton, Mass. (B.A.T.); and Exact Sciences, Marlborough, Mass. (M.E.R.). Address reprint requests to $D r$. Imperiale at the Regenstrief Institute, 1050 Wishard Blvd. Indianapolis, IN 46202.

*The members of the Colorectal Cancer Study Group are listed in the Appendix.

N Engl J Med 2004;351:2704-14.

Copyright $\odot 2004$ Massachusetts Medical Society.
BACKGROUND

Although fecal occult-blood testing is the only available noninvasive screening method that reduces the risk of death from colorectal cancer, it has limited sensitivity. We compared an approach that identifies abnormal DNA in stool samples with the Hemoccult II fecal occult-blood test in average-risk, asymptomatic persons 50 years of age or older.

METHODS

Eligible subjects submitted one stool specimen for DNA analysis, underwent standard Hemoccult II testing, and then underwent colonoscopy. Of 5486 subjects enrolled, 4404 completed all aspects of the study. A subgroup of 2507 subjects was analyzed, including all those with a diagnosis of invasive adenocarcinoma or advanced adenoma plus randomly chosen subjects with no polyps or minor polyps. The fecal DNA panel consisted of 21 mutations.

\section{RESULTS}

The fecal DNA panel detected 16 of 31 invasive cancers, whereas Hemoccult II identified 4 of 31 ( 51.6 percent vs. 12.9 percent, $\mathrm{P}=0.003$ ). The DNA panel detected 29 of 71 invasive cancers plus adenomas with high-grade dysplasia, whereas Hemoccult II identified 10 of 71 (40.8 percent vs. 14.1 percent, $\mathrm{P}<0.001$ ). Among 418 subjects with advanced neoplasia (defined as a tubular adenoma at least $1 \mathrm{~cm}$ in diameter, a polyp with a villous histologic appearance, a polyp with high-grade dysplasia, or cancer), the DNA panel was positive in 76 (18.2 percent), whereas Hemoccult II was positive in 45 (10.8 percent). Specificity in subjects with negative findings on colonoscopy was 94.4 percent for the fecal DNA panel and 95.2 percent for Hemoccult II.

CONCLUSIONS

Although the majority of neoplastic lesions identified by colonoscopy were not detected by either noninvasive test, the multitarget analysis of fecal DNA detected a greater proportion of important colorectal neoplasia than did Hemoccult II without compromising specificity. 
OLORECTAL CANCER IS THE SECOND leading cause of death from cancer among adults. ${ }^{1,2}$ Despite recommendations endorsing screening, less than 40 percent of people 50 years of age or older undergo screening for colorectal cancer. ${ }^{3}$ Guaiac-based chemical detection of fecal occult blood is the only noninvasive screening method with proven effectiveness, reducing both the incidence ${ }^{4}$ and the risk of death from colorectal cancer $^{5-7}$ when used programmatically. However, the sensitivity of fecal occult-blood testing for colorectal cancer and especially for colorectal adenomas is low because neoplasms may not bleed and thus cannot be detected in this way. ${ }^{2}$ The availability of a simple, noninvasive test that detects tumorspecific products with reasonable sensitivity and specificity might overcome barriers to screening among patients who are not willing to undergo more sensitive but more invasive tests, such as colonoscopy.

The molecular genetics of colorectal cancer provides the basis for the analysis of fecal DNA. ${ }^{8,9}$ Eighty-five percent of colorectal cancers result from chromosomal instability, with mutations progressively accumulating in the adenomatous polyposis coli (APC) gene, the p53 tumor-suppressor gene, and the K-ras oncogene. ${ }^{10}$ The other 15 percent arise from a loss of genes involved in DNA-mismatch repair, manifested by microsatellite instability. ${ }^{11} \mathrm{Co}-$ lorectal cancer may also be detectable through the use of DNA markers associated with disordered apoptosis. $^{12}$

Previous studies using fecal-based DNA testing have reported a sensitivity of 62 to 91 percent for cancer and 27 to 82 percent for advanced adenomas, with a specificity of 93 to 96 percent in persons with normal findings on colonoscopy. ${ }^{13-17}$ However, those studies assessed persons with advanced, symptomatic lesions. We made a head-to-head comparison of a fecal-based, multitarget DNA panel with Hemoccult II in asymptomatic adults, 50 years of age or older, who were at average risk for colorectal cancer. The primary objective was to compare detection rates for colorectal cancer and for colorectal cancer plus adenomas with high-grade dysplasia.

\section{METHODS}

STUDY DESIGN AND RATIONALE

The rationale for the study was based on screening guidelines indicating that newer screening tests need not demonstrate a reduction in cost-specific mortality but should be at least as sensitive, specific, and safe, among other features, as current screening tests. ${ }^{18}$ Hemoccult II (Beckman Coulter, formerly SmithKline Diagnostics) was chosen for the comparison with the DNA panel because it is the only fecal occult-blood test proven to reduce the incidence and risk of death from colorectal cancer and is the most widely used guaiac-based test. ${ }^{2}$ The study was designed by the authors, with advice from national experts on colorectal cancer, cancer screening and prevention, and study design.*

The study was conducted at 81 sites, including private-practice and university-based settings. Subjects were enrolled between August 2001 and March 2003. All subjects first provided a fecal sample for DNA testing and then completed three Hemoccult II cards before undergoing screening colonoscopy. All tests were conducted in a blinded fashion. Stool samples were analyzed for DNA abnormalities without knowledge of Hemoccult II or colonoscopy results; colonoscopy was performed without knowledge of the results of fecal DNA testing. Since Hemoccult II testing was conducted at the study sites, the results were potentially available to the colonoscopists. A clinical research organization (Parexel) received the results of Hemoccult II tests and colonoscopy directly from the clinical sites and received the results of fecal DNA analyses from the clinical laboratory (Exact Sciences).

Parexel conducted the data analyses according to a prespecified plan and provided the results to the investigators after completion of the study. Only Parexel had access to the data until the blinding was removed, at which time the information was shared with the authors. The authors wrote the article; Exact Sciences guaranteed the first author the right to publish the results of the study regardless of the outcome. Parexel, CareStat (the company that provided biostatistical support), and the authors each independently vouch for the veracity of the data and data analysis.

\section{STUDY POPULATION}

The target population consisted of asymptomatic persons at average risk for colorectal cancer. The appropriate institutional review board at each site approved the study. Written informed consent was obtained from all participants. Study sites recruited persons from local practices and undertook ac-

*See NAPS document no. PC0001 for 112 pages of supplementary material regarding the study protocol. To order, contact NAPS, c/o Burrows Systems, P.O. Box 3976, New Hyde Park, NY 11040. 
tivities to enhance the public's awareness of colorectal cancer and the availability of screening. The costs of colonoscopy were not covered by the study; Hemoccult II and fecal DNA testing was provided without charge. Participants were compensated in a manner approved by each site's institutional review board.

All participants were at least 50 years old. Enrollment was stratified according to age, with a minimum of three quarters of subjects 65 years of age or older. Exclusion criteria included gastrointestinal bleeding within the preceding month, a change in bowel habits or a recent onset of abdominal pain, previous colorectal cancer or polyps, prior resection of any part of the colon, iron-deficiency anemia, or other coexisting visceral cancer. Persons who had undergone colonoscopy, sigmoidoscopy, or double-contrast barium enema within the preceding 10 years or who had had a positive fecal occultblood test within the preceding 6 months were excluded, as were those with inflammatory bowel disease, familial adenomatous polyposis or hereditary nonpolyposis colon cancer, more than one firstdegree relative with colorectal cancer, or any firstdegree relative with colorectal cancer before the age of 50 years. Persons unwilling or unable to undergo colonoscopy were also excluded.

\section{PROCEDURES}

Subjects were given detailed instructions for stool collection; no dietary or medication modifications were required. Specimens were shipped directly to the clinical laboratory in a bar-coded container, chilled to between 0 and $4^{\circ} \mathrm{C}$. Specimens were required to arrive within 72 hours after collection; a minimal $30-\mathrm{g}$ sample was required. If a sample failed to meet these requirements, another sample was sought before colonoscopy was performed. Samples were stored at $-80^{\circ} \mathrm{C}$ until analysis.

Subjects were given three Hemoccult II cards and instructions regarding dietary and medication modifications to comply with current recommendations. ${ }^{1,19,20}$ Cards were returned to physicians' offices for non-rehydrated analysis by the physician or a designee, consistent with the manufacturer's instructions and current guidelines. If all three cards (six panels) were not completed, additional cards were provided.

Colonoscopy was performed with the preparation and sedation customarily used at each site. The colonoscopist documented the extent of the colon that was visualized and the quality of the bowel preparation. Adequate colonoscopy required visualization of the cecum and a minimum of 90 percent of the mucosa. The size and location of any lesions were recorded. Biopsy and surgical resection specimens were examined histopathologically at each site; no centralized pathological review was performed.

Subjects could be evaluated only if the specimen for fecal DNA analysis was adequate, all six Hemoccult II panels had been completed, and colonoscopy was adequate. Subjects were classified according to the most advanced lesion identified. Advanced adenoma was defined as any lesion containing high-grade dysplasia, a polyp containing clinically significant villous architecture, or a tubular adenoma that was at least $1 \mathrm{~cm}$ in diameter. Minor polyps included tubular adenomas less than $1 \mathrm{~cm}$ in diameter and hyperplastic polyps.

Parexel provided the clinical laboratory with a coded list of stool specimens to be analyzed for DNA abnormalities on the basis of colonoscopy and pathological reports. The prespecified analytic plan was designed to maximize the study's efficiency without compromising measures of sensitivity, specificity, and adherence to the protocol. DNA analysis was performed on stool samples from all subjects with an invasive cancer or advanced adenoma who could be evaluated and on randomly selected subgroups of 600 subjects with minor polyps and 1400 subjects with no polyps; these groups comprised the analyzed subgroup.

\section{FECAL DNA ANALYSIS}

All samples analyzed for fecal DNA were processed in a single laboratory. The fecal DNA panel consisted of 21 mutations: 3 in the K-ras gene, 10 in the $A P C$ gene, and 8 in the $p 53$ gene; the microsatelliteinstability marker BAT-26; and a marker of long DNA thought to reflect disordered apoptosis of cancer cells sloughed into the colonic lumen. ${ }^{13,14,16}$ The plan for DNA analyses has been described previously ${ }^{13,16}$ and is shown in Figure 1. Laboratory handling of all samples was fully automated, and quantitative analysis of the area under the curve, a measure of signal intensity of the labeled nucleotides, was compared with that for control DNA fragments with a known mutation. Each marker was assessed independently; a positive result for any component of the panel constituted a positive fecal DNA test. Laboratory technicians were unaware of both the clinical data associated with each sample and the sampling protocol. 


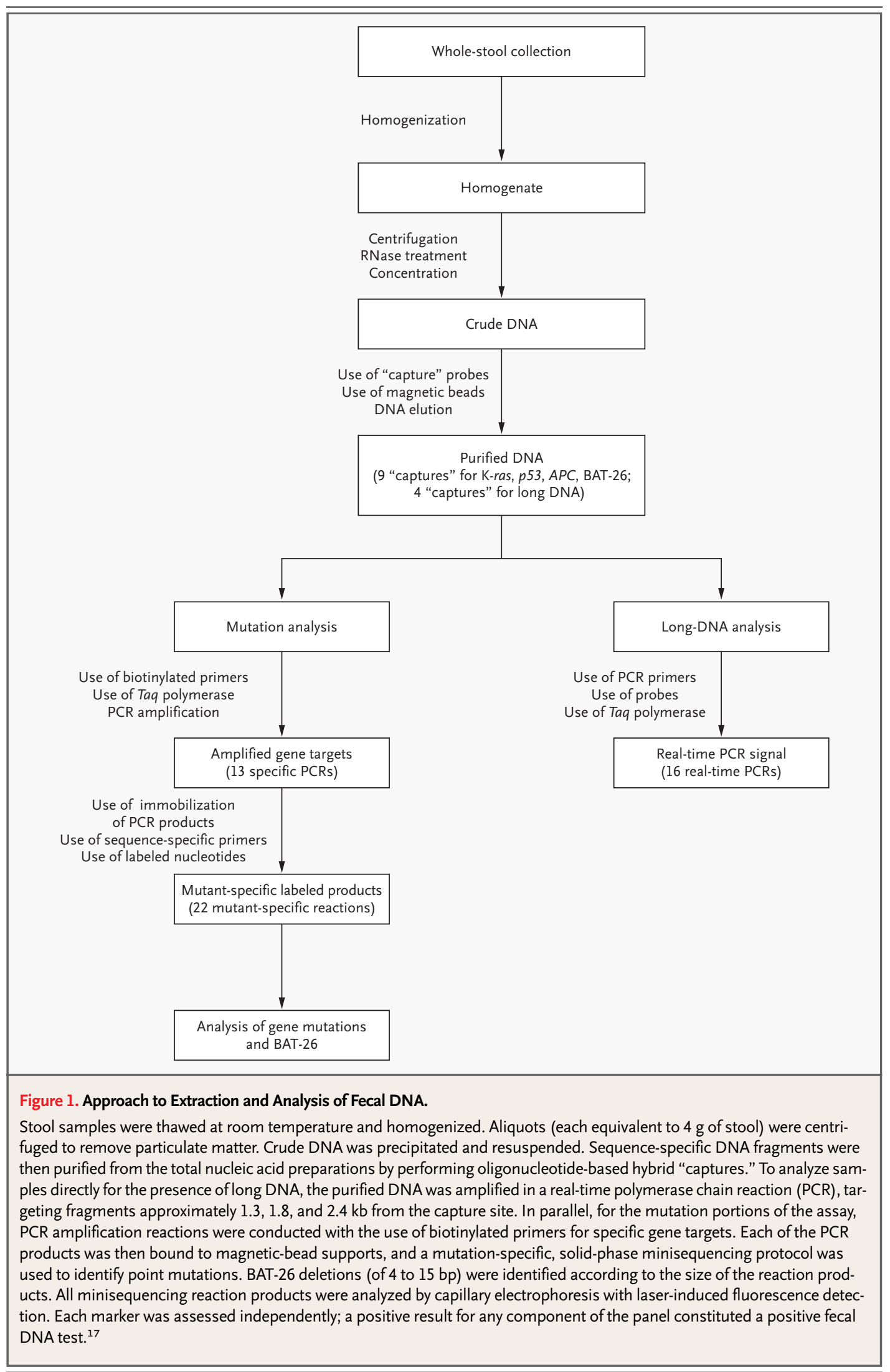




\section{STATISTICAL ANALYSIS}

The sample size was predetermined on the basis of the assumption that the fecal DNA panel and Hemoccult II had a sensitivity for the detection of colorectal cancer (i.e., tumor-node-metastasis [TNM] stage I through IV) of at least 65 percent and no more than 25 percent, respectively. Given this assumption, the enrollment of 32 subjects with colorectal cancer would provide the study with a statistical power of 90 percent to detect a significant difference at a two-sided alpha level of 0.05 with the use of McNemar's test. ${ }^{21} \mathrm{~A}$ post hoc McNemar's test was performed to compare the ability of the fecal DNA panel and Hemoccult II to identify subjects with fully specified advanced neoplasia (advanced adenoma or cancer). No interim analyses were performed, and missing data were not imputed.

\section{RESULTS}

\section{STUDY POPULATION}

A total of 5486 subjects were enrolled, of whom 4404 could be fully evaluated; 1082 (19.7 percent) could not be evaluated (Fig. 2). The demographic and clinical characteristics of the population that could be evaluated and the subgroup that was analyzed were similar (Table 1 ).

Colonoscopic findings are shown in Table 2. Invasive adenocarcinoma was identified in 31 subjects (a prevalence of 0.7 percent). The higher prevalence of pathological findings in the analyzed subgroup reflects the prespecified sampling strategy for stool processing in subjects with either no polyps or minor polyps. The only clinically significant complications were four colonoscopic perforations among 4404 subjects ( 0.09 percent).

\section{FECAL DNA PANEL VERSUS HEMOCCULT II}

The fecal DNA panel detected 16 of 31 invasive cancers (TNM stage I, II, or III), for a sensitivity of 51.6 percent; Hemoccult II detected 4 of 31 cancers, for a sensitivity of 12.9 percent (Table 2). The fecal DNA panel detected 13 cancers that were missed by Hemoccult II, whereas Hemoccult II detected 1 cancer that was missed by the panel. This difference in discordant test results was significant ( $\mathrm{P}=0.003$ ). In a post hoc analysis among subjects with node-negative disease (TNM stage I or II), the sensitivity of the fecal DNA panel was statistically superior to that of Hemoccult II (56.5 percent vs. 13.0 percent, $\mathrm{P}=0.006$ ). Among persons with TNM stage 0 , I, II, or III (TNM 0 is carcinoma in situ), the fecal DNA panel had a sensitivity of 40.8 percent, whereas Hemoccult II had a sensitivity of 14.1 percent. The fecal DNA panel detected 22 lesions that were missed by Hemoccult II, whereas Hemoccult II detected 3 lesions missed by the panel. This difference in discordant test results was significant $(\mathrm{P}<0.001)$.

Among the 40 subjects who had adenomas with high-grade dysplasia, the fecal DNA panel detected 13 of the adenomas (32.5 percent), whereas Hemoccult II detected 6 (15.0 percent). For the detection of other advanced adenomas (villous polyps and tubular adenomas $1 \mathrm{~cm}$ in diameter or larger) and for minor polyps, the sensitivities of both tests were consistently less than 20 percent (Table 2). Among 418 subjects with advanced neoplasia (defined as a tubular adenoma $1 \mathrm{~cm}$ in diameter or larger, a polyp with a villous histologic appearance, a polyp with high-grade dysplasia, or cancer), the DNA panel was positive in 76 subjects, whereas Hemoccult II was positive in 45 subjects (18.2 percent vs. 10.8 percent, $\mathrm{P}=0.001$ ). There was no significant difference in sensitivity according to the size of the cancer or advanced adenoma for either test (data not shown).

Among 1423 subjects with negative findings on colonoscopy, 79 had a positive fecal DNA panel and 68 had a positive Hemoccult II test, for specificities of 94.4 percent and 95.2 percent, respectively (Table 2). Among subjects with minor polyps, specificities for the fecal DNA panel and Hemoccult II were 92.4 percent and 95.2 percent, respectively.

Table 3 shows the frequencies of abnormal components of the fecal DNA panel as they relate to the various histologic findings. All components of the panel contributed to the overall sensitivity of the test. Although no formal statistical analysis was performed because of the small size of the subgroups, the sensitivities of the point mutations in APC, $p 53$, and K-ras were generally greater than those for the BAT-26 and long-DNA markers for clinically important lesions.

\section{DISCUSSION}

We compared a panel of fecal DNA markers and Hemoccult II as screening tests for colorectal cancer in an average-risk, asymptomatic population. The sensitivity of the fecal DNA panel was four times that of Hemoccult II for invasive cancer and more than twice as sensitive for adenomas con- 


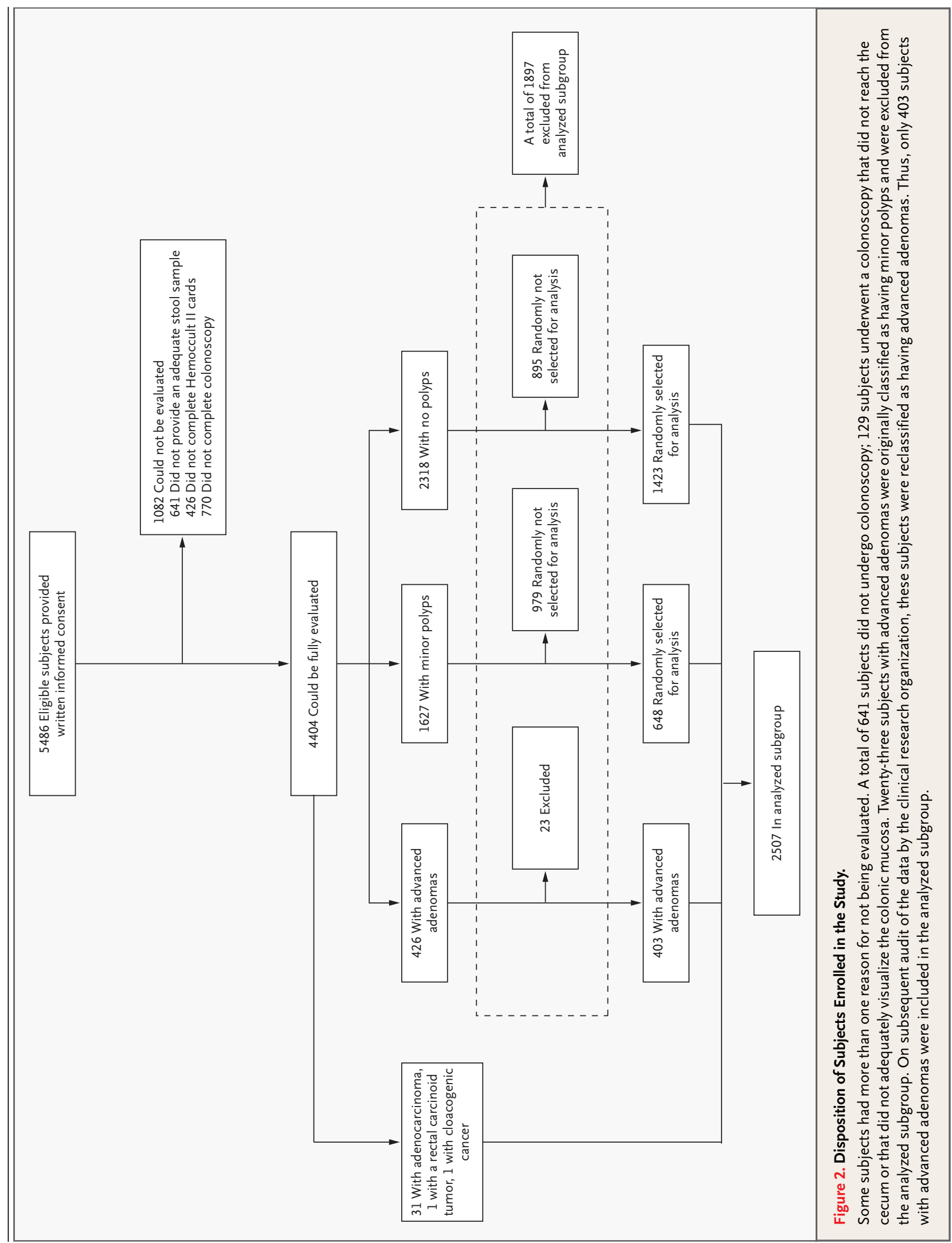




\begin{tabular}{|c|c|c|}
\hline \multicolumn{3}{|c|}{$\begin{array}{l}\text { Table 1. Characteristics of Subjects Who Could Be } \\
\text { Evaluated and Those Who Were Analyzed. }\end{array}$} \\
\hline Characteristic & $\begin{array}{l}\text { Group That } \\
\text { Could Be } \\
\text { Evaluated } \\
(\mathrm{N}=4404)\end{array}$ & $\begin{array}{l}\text { Analyzed } \\
\text { Subgroup } \\
(\mathrm{N}=2507)\end{array}$ \\
\hline \multicolumn{3}{|l|}{ Age } \\
\hline Mean - yr & 68.6 & 69.5 \\
\hline $50-59$ yr - no. (\%) & 570 (12.9) & $210(8.4)$ \\
\hline 60-69 yr - no. (\%) & $1971(44.8)$ & 1150 (45.9) \\
\hline 70-79 yr - no. (\%) & $1678(38.1)$ & 1025 (40.9) \\
\hline$\geq 80 \mathrm{yr}-$ no. (\%) & $185(4.2)$ & $122(4.9)$ \\
\hline Male sex - no. (\%) & $1963(44.6)$ & 1115 (44.5) \\
\hline \multicolumn{3}{|l|}{$\begin{array}{c}\text { Race or ethnic group } \\
\text { - no. (\%) }\end{array}$} \\
\hline White & $3846(87.3)$ & $2180(87.0)$ \\
\hline Black & $369(8.4)$ & $217(8.7)$ \\
\hline Other & $189(4.3)$ & $110(4.4)$ \\
\hline $\begin{array}{l}\text { Family history of colorectal } \\
\text { cancer - no. (\%) }\end{array}$ & $615(14.0)$ & 348 (13.9) \\
\hline
\end{tabular}

taining high-grade dysplasia. This increase in sensitivity was achieved without a loss of specificity among persons with no polyps on colonoscopy. Although this study was not powered to compare the tests among the different stages of cancer, the fecal DNA panel appears to be more sensitive than Hemoccult II for the detection of early (TNM stage I or II) colorectal cancer. However, since this result was not prespecified in the analytic plan, it should be considered preliminary.

The sensitivity of the fecal DNA panel for the detection of cancer was lower than that in previous reports. ${ }^{13,14,16,17,22,23}$ Using a similar panel, Ahlquist and colleagues reported a sensitivity of 90 percent for cancer and 82 percent for advanced adenomatous polyps. ${ }^{13}$ They used archived stool specimens from patients with known cancer, many of whom had advanced disease. The differences in test characteristics between their study and ours may be explained by differences in the clinical spectrum of disease (e.g., tumor size, tumor stage, or location within the colon) and study methods. Tagore et al. used an identical panel of markers to analyze stool specimens from 52 patients with colorectal cancer and 28 patients with advanced adenomas and reported sensitivities of 64 percent and 57 percent, respectively. ${ }^{16}$ Despite the predominance of distal lesions in that study, the test characteristics are closer to those in our study. In other studies, with the use of different panels of markers or different techniques, the sensitivity for the detection of cancer has ranged from 37 percent to 71 percent. ${ }^{14,17,22,23}$ However, none of these studies examined asymptomatic persons exclusively.

After we designed our protocol, the detection of "advanced neoplasia" became a popular outcome measure for studies involving screening for colorectal cancer. ${ }^{24-28}$ This term includes more advanced polyps with respect to size (tubular adenomas $1 \mathrm{~cm}$ in diameter or larger), histologic findings (villous architecture or high-grade dysplasia), or both features, along with invasive cancer. We compared the sensitivity of the fecal DNA panel with that of Hemoccult II in a post hoc analysis of the detection of all cases of advanced colorectal neoplasia, which included cancers and advanced adenomas. The fecal DNA panel detected 18.2 percent of samples with advanced neoplasia, whereas Hemoccult II identified 10.8 percent. The sensitivity of the DNA panel for advanced adenomas was lower than previously reported, ${ }^{15-17,29}$ although the confidence intervals overlap those in other reports. A plausible explanation for this difference in sensitivity is a decrease in exfoliation of cells owing to smaller adenoma size, since our subjects had smaller advanced adenomas than those in other studies (data not shown).

The sensitivity of Hemoccult II -13 percent for the detection of cancer - is lower than that reported in other series. ${ }^{25,30,31}$ Our finding should most appropriately be compared with the results of previous studies in which a reference standard such as colonoscopy was used in all subjects, irrespective of the results of the fecal occult-blood test. The most relevant study reported a sensitivity for cancer of 21 percent among 1217 subjects who were undergoing surveillance colonoscopy after curative resection of a colorectal neoplasm; these results are consistent with our findings. ${ }^{30}$ Lieberman and Weiss identified 12 of 24 patients with invasive cancer using rehydrated samples for Hemoccult II. ${ }^{25}$ We did not rehydrate the Hemoccult II cards, an approach that is consistent with published guidelines. ${ }^{2,19,20}$ Our sensitivity results for Hemoccult II may more closely reflect its sensitivity in clinical practice; the difference between our results and those of other reports is potentially important and deserves further study.

An advantage of using DNA as the analyte is that a marker panel can be expanded or refined as knowledge about tumor biology evolves. It is worth noting that in our study the sensitivity of the specific 


\begin{tabular}{|c|c|c|c|c|c|c|}
\hline \multirow[t]{2}{*}{$\begin{array}{l}\text { Most Advanced Finding } \\
\text { at Colonoscopy }\end{array}$} & \multirow[t]{2}{*}{$\begin{array}{l}\text { Group That } \\
\text { Could Be } \\
\text { Evaluated } \\
(\mathrm{N}=4404)\end{array}$} & \multirow{2}{*}{$\begin{array}{l}\text { Analyzed } \\
\text { Subgroup } \\
(\mathrm{N}=\mathbf{2 5 0 7 ) \dagger}\end{array}$} & \multicolumn{2}{|c|}{ Positive Fecal DNA Panel } & \multicolumn{2}{|c|}{ Positive Occult-Blood Test } \\
\hline & & & no./total no. & $\%(95 \% \mathrm{Cl})$ & no./total no. & $\%(95 \% \mathrm{Cl})$ \\
\hline Adenocarcinoma & 31 & 31 & $16 / 31$ & $51.6(34.8-68.0)$ & $4 / 31$ & $12.9(5.1-28.9)$ \\
\hline TNM stage I & 15 & 15 & $8 / 15$ & $53.3(30.1-75.2)$ & $1 / 15$ & $6.7(1.2-29.8)$ \\
\hline TNM stage II & 8 & 8 & $5 / 8$ & $62.5(30.6-86.3)$ & $2 / 8$ & $25.0(7.1-59.1)$ \\
\hline TNM stage III & 8 & 8 & $3 / 8$ & $37.5(13.7-69.4)$ & $1 / 8$ & $12.5(2.2-47.1)$ \\
\hline TNM stage IV & 0 & 0 & 0 & & 0 & \\
\hline $\begin{array}{l}\text { Adenocarcinoma + high-grade } \\
\text { dysplasia }\end{array}$ & 72 & 71 & $29 / 71$ & $40.8(30.2-52.5)$ & $10 / 71$ & $14.1(7.8-24.6)$ \\
\hline Advanced adenoma & 426 & 403 & $61 / 403$ & $15.1(12.0-19.0)$ & $43 / 403$ & $10.7(8.0-14.1)$ \\
\hline High-grade dysplasia & 41 & 40 & $13 / 40$ & $32.5(20.1-48.0)$ & $6 / 40$ & $15.0(7.1-29.1)$ \\
\hline Villous adenoma & 139 & 133 & $24 / 133$ & $18.0(12.4-25.4)$ & $13 / 133$ & $9.8(5.8-16.0)$ \\
\hline Tubular adenoma $\geq 1 \mathrm{~cm}$ & 230 & 214 & $23 / 214$ & $10.7(7.3-15.6)$ & $22 / 214$ & $10.3(6.9-15.1)$ \\
\hline Unspecified & 16 & 16 & $1 / 16$ & $6.2(1.1-28.3)$ & $2 / 16$ & $12.5(3.5-36.0)$ \\
\hline Minor polyps & 1627 & 648 & $49 / 648$ & $7.6(5.8-9.9)$ & $31 / 648$ & $4.8(3.4-6.7)$ \\
\hline Tubular adenoma $<1 \mathrm{~cm}$ & 762 & 286 & $23 / 286$ & $8.0(5.9-12.7)$ & $15 / 286$ & $5.2(3.5-9.2)$ \\
\hline Hyperplastic & 633 & 276 & $17 / 276$ & $6.2(3.9-9.6)$ & $10 / 276$ & $3.6(2.0-6.5)$ \\
\hline Unspecified & 232 & 86 & $9 / 86$ & $10.5(5.6-18.7)$ & $4 / 86$ & $4.6(1.8-11.4)$ \\
\hline No polyps on colonoscopy $\mathbb{\int}$ & 2318 & 1423 & $79 / 1423$ & $5.6(4.5-6.9)$ & $68 / 1423$ & $4.8(3.9-5.8)$ \\
\hline
\end{tabular}

* The total in both the group that could be evaluated and the analyzed subgroup includes two subjects who are not included in any other category in the table; one had a rectal carcinoid, and one had cloacogenic cancer. The subject with rectal carcinoid was not identified by means of either fecal DNA or by fecal occult-blood testing. The subject with cloacogenic cancer was identified by means of fecal DNA testing, but not by fecal occult-blood testing. CI denotes confidence interval, and TNM tumor-node-metastasis.

$\uparrow$ Stool specimens were selected for DNA testing on the basis of available data (i.e., polyp size and histologic findings) at the time of selection for processing. Subsequent audit of data by the clinical research organization resulted in reclassification of less than 5 percent of subjects.

$\uparrow$ The fecal DNA panel had a specificity of 92.4 percent, and the occult-blood test had a specificity of 95.2 percent ( 95 percent confidence interval for the difference in specificity, -5.4 percent to 0.1 percent).

$\int$ The fecal DNA panel had a specificity of 94.4 percent, and the occult-blood test had a specificity of 95.2 percent ( 95 percent confidence interval for the difference in specificity, -2.4 percent to 0.9 percent).

gene-mutation components of the panel for the detection of cancer was similar to that in previous studies involving symptomatic patients. ${ }^{13,16,22}$ The sensitivity of the long-DNA assay component was lower than expected, a finding that may be related to DNA degradation. This first-generation assay panel has already been improved by enhanced techniques for extraction of human DNA from stool. ${ }^{32}$

Our study has certain limitations. First, persons 65 years of age and over were disproportionately represented in the study population. However, there is no reason to expect the distribution of DNA abnormalities to vary according to age; the observed sensitivity is likely to apply to younger populations with a lower prevalence of advanced neoplasia. Second, the study was designed as a direct comparison of two noninvasive screening methods; there were too few cancers and advanced adenomas with highgrade dysplasia to provide narrow confidence intervals for the estimated sensitivity of either test. Third, no inference can be drawn about the appropriate interval for retesting or the effectiveness of repeated testing with the fecal DNA panel. Fourth, whereas all DNA analyses of samples were performed in a single laboratory with extensive experience in the use of the assay, widespread use could introduce variability that would affect the sensitivity and specificity.

The place of fecal DNA testing in the current scheme of colorectal-cancer screening is beyond the scope of this discussion. The issue requires consideration of the characteristics of the test, risk, 


\begin{tabular}{|c|c|c|c|c|c|c|c|}
\hline \multirow[t]{3}{*}{$\begin{array}{l}\text { Most Advanced Finding } \\
\text { at Colonoscopy }\end{array}$} & \multirow[t]{3}{*}{$\begin{array}{l}\text { Total } \\
\text { No. }\end{array}$} & \multicolumn{6}{|c|}{ Positive Fecal DNA } \\
\hline & & Overall & K-ras & $p 53$ & $A P C$ & BAT-26* & $\begin{array}{l}\text { Long } \\
\text { DNA }\end{array}$ \\
\hline & & \multicolumn{6}{|c|}{ number (percent) } \\
\hline Adenocarcinoma & 31 & $16(51.6)$ & $5(16.1)$ & $8(25.8)$ & $9(29.0)$ & $2(6.5)$ & $1(3.2)$ \\
\hline Advanced adenoma & 403 & $61(15.1)$ & $18(4.5)$ & $11(2.7)$ & $27(6.7)$ & $5(1.2)$ & $8(2.0)$ \\
\hline High-grade dysplasia & 40 & $13(32.5)$ & $5(12.5)$ & $2(5.0)$ & $3(7.5)$ & 0 & $5(12.5)$ \\
\hline Other & 363 & $48(13.2)$ & $13(3.6)$ & $9(2.5)$ & $24(6.6)$ & $5(1.4)$ & $3(0.6)$ \\
\hline Minor polyps & 648 & $49(7.6)$ & $19(2.9)$ & $5(0.8)$ & $16(2.5)$ & $4(0.6)$ & $8(1.2)$ \\
\hline No polyps on colonoscopy & 1423 & $79(5.6)$ & $22(1.5)$ & $16(1.1)$ & $11(0.8)$ & $16(1.1)$ & $18(1.3)$ \\
\hline
\end{tabular}

* BAT-26 is a microsatellite-instability marker.

$\dagger$ A marker of long DNA is thought to reflect disordered apoptosis of cancer cells sloughed into the colonic lumen.

cost, interval between tests, acceptability to patients, and compliance. Although colonoscopy is superior to other tests in some respects, the Preventive Services Task Force has determined that no single test or strategy for colorectal-cancer screening can be endorsed on the basis of currently available data. ${ }^{33}$ Several approaches (fecal occult-blood testing, sigmoidoscopy, colonoscopy, and barium enema examination) are included as options in the screening guidelines. ${ }^{1,18,34,35}$ Despite technical advances in computed tomographic ("virtual") colonoscopy, there is a lack of consensus about its role in screening. ${ }^{36}$ The low sensitivity of the fecal DNA panel for detecting clinically significant neoplasia might limit its value as a one-time test for cancer, since it misses most lesions identified on colonoscopy. However, the use of a less sensitive test at frequent intervals in a program of screening may be as effec- tive for the detection of important neoplasia as a more sensitive test that is used infrequently, such as colonoscopy. ${ }^{33}$ Further study would be required to assess this issue. Nonetheless, the availability of an accurate, noninvasive test might remove one of the barriers to more widespread screening.

Supported by grants from Exact Sciences.

Dr. Imperiale reports having received consulting fees and grant support from Exact Sciences. Dr. Ransohoff was chair of the Scientific Advisory Board of Exact Sciences from October 2000 through April 2002. Dr. Itzkowitz reports having received grant support from Exact Sciences and is a member of the speakers' bureau for Myriad Genetics Laboratories and AstraZeneca Pharmaceuticals. Dr. Turnbull is an employee of CareStat. Dr. Ross is a former employee and current shareholder of Exact Sciences.

We are indebted to Kathleen Morel, Joy Yucaitis, and the staff at Parexel for their assistance throughout the study; to Duncan Whitney, Ph.D., for assistance with manuscript preparation; to the clinical laboratory staff at Exact Sciences for processing the stool samples; to Robert H. Fletcher, M.D., M.Sc., for critical review of an earlier version of the manuscript; and to the patients and staff at the clinical study sites.

The Colorectal Cancer Study Group includes the following investigators: J. Agaibui, Aurora Healthcare, Gurnee, Ill.; K. Ashby, Saddleback Medical Group, Laguna Hills, Calif.; R. Baerg, Tacoma Digestive Disease Center, Tacoma, Wash.; C. Barish, Wake Research Associates, Raleigh, N.C.; W. Bennetts, NW Gastroenterology Clinic, Portland, Oreg.; B. Bowling, Regional Clinical Research, Endwell, N.Y.; S. Brady, Anchor Research, Naples, Fla.; W. Bray, Digestive Health Specialists, Winston-Salem, N.C.; R. Chasen, Maryland Digestive Disease, Laurel, Md.;J. Church, Cleveland Clinic, Cleveland; L. Cohen, Research Associates of New York, New York; P. Coleman, PCM Medical Services, Lansing, Mich.; D. Connell, Regional Gastroenterology Association of Lancaster, Lancaster, Pa.; K. Davis, Sadler Clinic, Conroe, Tex.; G. Dunegan, Physicians Research Network, Houston; T. Feinstat, Capitol Gastroenterology Consultants Medical Group, Roseville, Calif.; H. Fields, Physicians Research Network, Houston; R. Foliente, Columbus Internal Medicine, Columbus, Ind.; J. Geenen, Wisconsin Center for Advanced Research, Milwaukee; W. George, Sound Research, Cadillac, Mich.; M. Glick, Lahey Clinic, Burlington, Mass.; S. Goldberg, Gastroenterology Associates of the East Bay Medical Group, Berkeley, Calif.; M. Goldstein, Long Island Gastrointestinal Research Group, Great Neck, N.Y.; J. Goldstein, University of Illinois, Chicago; S. Golpalani, Physicians Research Network, Houston; M. Gurney, Gastroenterology Specialists, Canton, Ohio; R. Hardi, Metropolitian Gastroenterology/Chevy Chase Clinical Research, Chevy Chase, Md.; W. Harlan, Asheville Gastroenterology Specialists, Asheville, N.C.; J. Harlan, Banner Healthcare, Phoenix, Ariz.; C. Howden, Northwestern University Center for Clinical Research, Chicago; W. Ignatowicz, Pharma Trials, Brooklyn, N.Y.; S. Itzkowitz, Mount Sinai School of Medicine, New York; R. Jacoby, University of Wisconsin Medical School, Madison; J. Johanson, Rockford Gastroenterology, Rockford, Ill.; D. Johnson, GI and Liver Specialists of Tidewater, Norfolk, Va.; M. Kelfer, Fallon Clinic, Worcester, Mass.; H. Klein, DMI Healthcare Group, Clearwater, 
Fla.; M. Koch, Capitol Gastroenterology Consultants, Silver Spring, Md.; D. Limauro, Ntouch Research, Pittsburgh; D. Maccini, Spokane Digestive Disease Center, Spokane, Wash.; L. Maletz, Center for Healthcare, San Diego, Calif.; M. McCartney, East Coast Clinical Research, Salisbury, Mass.; J. McNerney, Tucson Therapeutic Research Institute, Tucson, Ariz.; T. Mendolia, Northwest Piedmont Clinical Research, Elkin, N.C.; D. Miller, Birmingham Gastroenterology Associates, Birmingham, Ala.; R. Moses, Philadelphia Gastroenterology Consultants, Huntingdon Valley, Pa.; M. Murphy, Southeastern Digestive and Liver Disease Institute, Savannah, Ga.; B. Pineau, Wake Forest University Baptist Medical Center, Winston-Salem, N.C.; J. Pressman, Medical Associates Research Group, San Diego, Calif.; M. Provenza, Louisiana Research Center, Shreveport; D. Riff, AGMG Clinical Research, Anaheim, Calif.; J. Rohlf, Sound Medical Research, Trenton, N.J.; D. Ronnerman, Advanced Clinical Concepts, Pottstown, Pa.; M. Round, Osczola Physicians Management, Kissimmee, Fla.; T. Ruffolo, Physician's East, Greenville, N.C.; M. Safdi, Consultants for Clinical Research, Cincinnati; B. Salzberg, Atlanta Gastroenterology Associates, Atlanta; P. Schleinitz, GI Consultants, Medford, Oreg.; C. Schmidt, Southeastern Clinical Research, Chattanooga, Tenn.; P. Schroy, Boston Medical Center, Boston; H. Schwartz, Miami Research Associates, Miami; R. Shaw, Health Care Link, Apoka, Fla.; D. Silvers, GI Research, Metairie, La.; D. Smoot, Howard University, Washington, D.C.; S. Sontag, Edward Hines Veterans Affairs Hospital, Hines, Ill.; D. Stanton, Community Clinical Trials, Orange, Calif.; L. Stein, Affiliates in Gastroenterology, Florham Park, N.J.; M. Stern, Ntouch Research, Decatur, Ga.; S. Syngal, Dana-Farber Cancer Institute, Boston; J. Terdiman, University of California at San Francisco-Cancer Risk Program, San Francisco; D. Weinberg, Fox Chase Cancer Center, Philadelphia; J. Weinstein, Pharma Trials, Hillsborough, N.J.; D. Winston, Cigna Healthcare, Sun City, Ariz.; B. Wittmer, Commonwealth Biomedical Research, Madisonville, Ky.; R. Wohlman, NW Gastroenterology Associates, Bellevue, Wash.; J. Wolosin, Regional Research Institute, Jackson, Tenn.; S. Woods, Gastroenterology Associates of Fairfield County, Bridgeport, Conn.; P. Yantis, Coastal Carolina Research Center, Mt. Pleasant, S.C.; D. Yarbrough, Physicians Research Network, Houston; and Z. Younes, Gastroenterology Center of Mid South, Memphis, Tenn.

REFERENCES

1. Smith RA, Cokkinides V, Eyre HJ. American Cancer Society guidelines for the early detection of cancer, 2003. CA Cancer J Clin 2003;53:27-43.

2. Ransohoff DF, Sandler RS. Screening for colorectal cancer. N EnglJ Med 2002;346 40-4.

3. Ahluwalia IB, Mack KA, Murphy W Mokdad AH, Bales VS. State-specific prevalence of selected chronic disease-related characteristics - Behavioral Risk Factor Surveillance System, 2001. MMWR Surveil Summ 2003;52:1-80.

4. Mandel JS, Church TR, Bond JH, et al The effect of fecal occult-blood screening on the incidence of colorectal cancer. N Eng J Med 2000;343:1603-7.

5. Mandel JS, Bond JH, Church TR, et al. Reducing mortality from colorectal cance by screening for fecal occult blood: Minnesota Colonoscopy Cancer Control Study. N Engl J Med 1993;328:1365-71. [Erratum, N Engl J Med 1993;329:672.]

6. Kronborg O, Fenger C, Olsen J, Jorgensen OD, Sondergaard O. Randomised study of screening for colorectal cancer with faecal-occult-blood test. Lancet 1996;348: 1467-71.

7. Hardcastle JD, Chamberlain JO, Robinson $\mathrm{MH}$, et al. Randomised controlled tria of faecal-occult-blood screening for colorectal cancer. Lancet 1996;348:1472-7.

8. Sidransky D, Tokino T, Hamilton SR, et al. Identification of ras oncogene mutations in the stool of patients with curable colorectal tumors. Science 1992;256:102-5. 9. Ahlquist DA, Shuber AP. Stool screening for colorectal cancer: evolution from occult blood to molecular markers. Clin Chim Acta 2002;315:157-68.

10. Lengauer C, Kinzler KW, Vogelstein B. Genetic instability in colorectal cancers. Nature 1997;386:623-7.

11. Thibodeau SN, Bren G, Schaid D. Microsatellite instability in cancer of the proximal colon. Science 1993;260:816-9.
12. Koornstra J, de Jong S, Hollema H, de Vries EG, Kleibeuker JH. Changes in apoptosis during the development of colorecta cancer: a systematic review of the literature. Crit Rev Oncol Hematol 2003;45:37-53.

13. Ahlquist DA, Skoletsky JE, Boynton KA et al. Colorectal cancer screening by detection of altered human DNA in stool: feasibility of a multitarget assay panel. Gastroenter ology 2000;119:1219-27.

14. Dong SM, Traverso G, Johnson C, et al Detecting colorectal cancer in stool with the use of multiple genetic targets. J Natl Cancer Inst 2001;93:858-65.

15. Syngal S, Chung D, Willet C, et al. The loss of stool DNA mutation abnormalities in colorectal neoplasia after treatment. Gastroenterology 2003;124:Suppl 1:A-5. abstract.

16. Tagore KS, Lawson MJ, Yucaitis JA, et al. Sensitivity and specificity of a stool DNA multitarget assay panel for the detection of advanced colorectal neoplasia. Clin Colorec tal Cancer 2003;3:47-53.

17. Traverso G, Shuber A, Levin B, et al Detection of APC mutations in fecal DNA from patients with colorectal tumors. $\mathrm{N}$ Engl J Med 2002;346:311-20.

18. Winawer S, Fletcher R, Rex D, et al. Colorectal cancer screening and surveillance: clinical guidelines and rationale - update based on new evidence. Gastroenterology 2003;124:544-60.

19. Suggested technique for fecal occult blood testing and interpretation in colorec tal cancer screening. Ann Intern Med 1997; 126:808-10.

20. Ransohoff DF, Lang CA. Screening for colorectal cancer with the fecal occult blood test: a background paper. Ann Intern Med 1997;128:811-22.

21. McNemar Q. Note on the sampling error of the difference between correlated proportions or percentages. Psychometrik 1947;12:153-7

22. Calistri D, Rengucci C, Bocchini R, Saragoni L, Zoli W, Amadori D. Fecal multiple molecular tests to detect colorectal cancer in stool. Clin Gastroenterol Hepatol 2003;1: 377-83.

23. Traverso G, Shuber A, Olsson L, et al. Detection of proximal colorectal cancers through analysis of faecal DNA. Lancet 2002; 359:403-4.

24. Lieberman DA, Weiss DG, Bond JH, Ahnen DJ, Garewal H, Chejfec G. Use of colonoscopy to screen asymptomatic adults for colorectal cancer: Veterans Affairs Cooperative Study Group 380. N Engl J Med 2000 343:162-8. [Erratum, N Engl J Med 2000; 343:1204.]

25. Lieberman DA, Weiss DG. One-time screening for colorectal cancer with combined fecal occult-blood testing and examination of the distal colon. N Engl J Med 2001; 345:555-60.

26. Imperiale $\mathrm{TF}$, Wagner $\mathrm{DR}$, Lin $\mathrm{CY}$, Larkin GN, Rogge JD, RansohoffDF. Using risk for advanced proximal colonic neoplasia to tailor endoscopic screening for colorectal cancer. Ann Intern Med 2003;139:959-65.

27. Pinsky PF, Schoen RE, Weissfeld JL, Bresalier RS, Hayes RB, Gohagan JK. Predictors of advanced proximal neoplasia in persons with abnormal screening flexible sigmoidoscopy. Clin Gastroenterol Hepatol 2003;1:103-10

28. Schoen RE, Pinsky PF, Weissfeld JL, et al. Results of repeat sigmoidoscopy 3 years after a negative examination. JAMA 2003; 290:41-8.

29. Ahlquist DA, Harrington JJ, Burgart LJ, Roche PC. Morphometric analysis of the "mucocellular layer" overlying colorectal cancer and normal mucosa: relevance to exfoliation and stool screening. Hum Pathol 2000;31:51-7.

30. Ahlquist DA, Wieand HS, Moertel CG, et al. Accuracy of fecal occult blood screening for colorectal neoplasia: a prospective study using Hemoccult and HemoQuant tests. JAMA 1993;269:1262-7.

31. Allison JE, Tekawa IS, Ransom LJ, Adrain 
FECAL DNA FOR COLORECTAL-CANCER SCREENING

AL. A comparison of fecal occult-blood tests for colorectal-cancer screening. $\mathrm{N}$ Engl J Med 1996;334:155-9.

32. Whitney D, Skoletsky J, Moore K, et al.

Enhanced retrieval of DNA from human feca

samples results in improved performance of

colorectal cancer screening test. J Mol Diagn

2004;6:386-95.

33. Pignone M, Saha S, Hoerger T, Mandel- blatt J. Cost-effectiveness analyses of colorectal cancer screening: a systematic review for the U.S. Preventive Services Task Force. Ann Intern Med 2002;137:96-104.

34. U.S. Preventive Services Task Force. Screening for colorectal cancer: recommendation and rationale. Ann Intern Med 2002; 137:129-31.

35. Pignone M, Rich M, Teutsch SM, Berg
AO, Lohr KN. Screening for colorectal cancer in adults at average risk: a summary of the evidence for the U.S. Preventive Services Task Force. Ann Intern Med 2002; 137:132-41.

36. Ransohoff DF. Virtual colonoscopy what it can do vs what it will do. JAMA 2004; 291:1772-4.

Copyright (c) 2004 Massachusetts Medical Society. 